\title{
Practices leading to information literacy development among Nigerian undergraduates
}

\author{
Iliasu Jinadu ${ }^{1,2}$ and K. Kiran ${ }^{1}$ \\ ${ }^{1}$ Department of Library \& Information Science, \\ Faculty of Computer Science \& Information Technology, University of Malaya, \\ 50603, Kuala Lumpur, MALAYSIA \\ ${ }^{2}$ College Library, Adeniran Ogunsanya College of Education, \\ KM 37, Badagry Expressway, Otto/ljanikin, Lagos, NIGERIA. \\ e-mail: jinaduiliasu@yahoo.com; kiran@um.edu.my (corresponding author)
}

\begin{abstract}
This study examines the practices of academics, as employees, to understand how information literacy skills (IL) evolve in the workplace (college context). The study uses the practice approach, relying on qualitative case study. Data are collected through in-depth interviews and nonparticipatory observations from nine (9) purposely selected Heads of Departments in a college of education in Nigeria. The findings highlight eight (8) practices through which the academics engage themselves and their undergraduates; and identify the information skills that may evolve from such practices. The study concludes that academics' practices may nurture IL skills to solve information seeking problems in academia as well as students' future workplace. The study reveals the need for future tracer studies that could investigate how other factors hinder or facilitate the performance of graduates (employees) in the workplace.
\end{abstract}

Keywords: Information literacy in the workplace; Workforce information literacy; Information seeking behaviour; Teacher educators; Undergraduate students.

\section{INTRODUCTION}

In the workplace whatever the employees are able to do or could not do may be traceable to, among others, the academic interactions they experience with their teachers at universities. D'Angelo's (2012) case study establishes that workplace performance is attributed, in part, to the evolution of information and communication technologies as well as the teaching and learning of different or higher levels of skills than what the colleges are currently able to deliver. The American Information Industry Association also calls for improvement of employees information skills in the workplace (Zurkowski 1974).

Most studies on information literacy (IL) skills concentrate on how information literacy (IL) is taught in a classroom setting (Rader 2002; Virkus 2011). Very few studies pay attention to how IL evolves in the workplace practices (Wang, Bruce and Hughes 2011) through the employees' inter-relations, experiences with artefacts, and work environment (Lloyd 2010). 


\section{LITERATURE REVIEW}

Researches on IL in the workplace are just emerging and experiencing some developmental challenges (Wang, Bruce and Hughes 2011). The few notable researches on IL in the workplace includes, Bruce (1997) involving higher education professionals including academics in Australia and the UK (Boon, Johnston and Webber 2007); Cheuk (1998) studying auditors in Singapore; Kirk (2004) investigating senior managers; Veinot (2007) involving a vault inspector; and Lloyd (2007) observing fire fighters and ambulance officers in Australia. These studies took the 'practice' approach in order to explore how employees interact among themselves, with the artefacts, and the environment in order to execute their tasks.

Practices in the workplace are determined by the role of the employee played out by executing the tasks demanded of each role. An employee could play more than one role in an organisation. An academic, for example may have multiple roles, as a lecturer, as head of department, and as an editor of the faculty's peer-review journal. All these roles are separated by the various tasks carried out to perform each role.

Bitso and Fourie (2012) posit that work roles lead to tasks that trigger information need and, depending on the nature of the information need, information seeking then occurs. The information need determines the choice of information sources that are being used. Following the relationship between work roles and tasks, Bitso and Fourie divide teachers' roles into: academic, administrative, and non-academic. All these roles have their specific tasks. Also working in the area of employee role and tasks, Koster, et al. $(2005$, p. 168) compile a professional profile of teacher educators, where the expected tasks (practices) are categorised into five: (i) professionalism and well-being, (ii) providing a teacher education programme, (iii) taking part in policy development and development in teacher education, (iv) organising activities for and with teachers, and (v) selecting future teachers. A look at these tasks suggests the multi-roles of teacher educators.

In another similar investigation, Smith (2005) categorises the tasks (practices) expected of teacher educator into eight: (i) facilitator of the learning process of the student teacher, (ii) encourager of reflective skills, (iii) developer of new curricula, (iv) gatekeeper, (v) researcher, (vi) stimulator of professional development for school teachers, (vii) teammember and (viii) collaborator (external contact) (p. 178). Smith's tasks, in comparison with other tasks mentioned in the literature, are similar and a few differences are noted in terms of semantics. Drawing from various definitions of IL, descriptions of components of IL, existing IL Standards, and models in the literature (Rader 2002; Virkus 2003; Lloyd 2010; Virkus 2011), the IL practices that could be expected and executed within the workplace tasks are:

- Task identification;

- Information need;

- Information access and retrieval;

- Information refining; synthesising and creating;

- Information dissemination and knowledge sharing;

- Team management;

- Career development and future practice; and

- Research and community development.

Salau (2012a; 2012b) observes that the skills to participate actively in the workplace are lacking among the employees in Nigeria. Workplace employees are partial products of their tertiary education. Since the society depends upon tertiary institutions to supply the 
nation's workforce for national development (Crawford 2013), there is a need to understand how practices among academics prepare their undergraduates to become information literate persons, who can actively participate in the twenty-first century workplace. Such understanding would help identify what intervention initiatives could be placed and at which point to enhance the development of IL skills among the undergraduates. Ross, Perkins and Bodey (2013) are concerned about the placement of IL instruction in higher education and its effect on students IL self-efficacy and suggest that IL should be designed and embedded in the curriculum after examining students in employment.

\section{OBJECTIVE AND METHOD}

This study explores how the practices among academics in a college in Nigeria affect IL skills among the undergraduates and aspects that might be applied in their future workplace. The study has one main objective i.e. to understand how the practices among academics may develop IL skills among undergraduates for their academic and future workplace skill needs.

The "workplace is an inter-subjective space" (Lloyd 2010, p. 89) that provides a platform to assess how IL is exhibited in the routine practices of employees. The activities in the workplace involve inter-relation and co-participation among employees. Given the value of the practice approach, this research chooses a qualitative case study approach, which is informed by the structure of the workplace and is recommended by Merriam (2001) that for the 'how' and 'why' questions in a single-bounded system, the case study has a distinct advantage. In addition, Yin (2011) argues that a research that intends to gather more information from a particular person or group of people should engage a case study approach. Furthermore, Neuman (2011) recommend qualitative research approach to allow the researcher to learn from participants' free expressions of their real world which necessitates the choice of a practice approach.

The practice approach involves understudying people and their activities as many social practices involves information seeking and sharing, information management, information creation and IL (Cox 2012a, p. 62). As the activities are executed in a practice, the skills necessary for and embedded in the practices are brought to the fore. In ascertaining what 'practice' is, Reckwitz (2002, p. 250) describes it as "a routinized way in which bodies are moved, objects are handled, subjects are treated, things are described and the world is understood". This description is holistic and would provide an understanding of the activities of people usually conveyed in a social sense as embodied, embedded in routines and material objects and their arrangement, closely linked to purposes, feelings and taste, transitory and situated (Cox 2012b).

The workplace employees carry out their routine practices by 'doing' something for other employees. In such doings, knowledge is shared, learning takes place and the novice become experienced. The benefit of the practice approach to workplace research is described by Wenger (1998) who argues that practice is doing, 'in a historical and social context that gives structure and meaning to what we do' (p. 47). Practice approach allows the researcher to see beyond individualism and appreciate communal efforts dispensed in a socio-cultural reality of everyday life. This relationship is described as a social practice through which employees execute their tasks (Moring and Lloyd 2013). Further to the practice approach, Jinadu and Kiran (2014) suggest a workplace IL model, which positions 
the employee as someone in the know and shares knowledge and experience with others at the worksite to foster learning in practice.

In addition, this study collects qualitative data from nine (9) academics who are heads of departments in a College of Education in Nigeria through in-depth interviews and nonparticipatory observations. The heads of departments are selected because of their exposure to more information practices than their colleagues, and the college is selected as the legitimate research site due to its recognition by donor organisations (UNICEF, UNESCO) and government agencies. The first researcher, in a prolonged engagement between August, 2013 and September, 2014 conducted multiple interview sessions with the participants and observed their activities in-situ. Member checking, external audit, and peer review were strategies used to achieve trustworthiness for this study. All the participants read and endorsed the transcripts as true reflection of the interview that was conducted. They also checked on the codes that emerged afterwards to ascertain that the meaning of the codes represent the intent of the participants' statements. Peer reviews are researchers' colleagues who are not part of data collection process but understand the methodology of conducting qualitative research. Two peers were appointed for this purpose and they checked the process of data collection and data analysis. They both submitted that the process of the research was rigorous, transparent and repeatable. Two lecturers: one Associate Professor and a Senior lecturer, currently teaching research methodology in their respective universities, were the external audits for this research. At intervals, the two lecturers were consulted to ensure that the research process was detailed and scientific enough. Relying on the 'Memoing' of the researchers, the external audits, on different occasions, affirmed the codes that emerged after data analysis. The content analysis was used to analyse transcribed verbalized data to look for practices assumed in academic roles and programmes, and identify the resultant IL components as well the IL skills intended.

\section{FINDINGS}

The content analysis reveals eight (8) main practices through which the academics engage their undergraduates. The practices involve interactions among academics and between academics and their students. Relying on the constant comparative technique of data analysis, the practices that were common and corroborated by other participants are reported here. Through the interviews and observation sections, the descriptions of the participants were mapped against existing literature in order to identify possible IL component and skill. The external audits and peer reviews were of the opinion that the process that identified the practices could be replicated. Each practice is further analysed to identify the possible IL component transfer from academics to their students or among academics themselves. Both are presented in order to explore the possible IL skills that may evolve from the practice.

\section{Residential Home Management Practicum (RHMP)}

Residential Home Management Practicum (RHMP) is a practice that brings academics and students together in a 'home role play'. Students are arranged into groups of about eight each and are put together to live as a family for the duration of the three-week practice. The participating academic (HHV2) explains that each lecturer in the department is mandated to compile a student profile right from the day of admission. The profile is a dossier, which indicates the student's strength, weakness, opportunities, and threats (SWOT) and determines the selection of students into the family. Each lecturer (including 
HHV2) is expected to use the students' SWOT profile to intervene where necessary to develop and improve students' skills. HHV2 explains that, the practice nurture students to develop skills of tolerance, human and material resources management, counselling and parenthood. The students are expected to role-play various types of family membership in the home on the understanding that a perfect home makes a good community or society. The lecturers are the supervisors and visit the home in turns to assess each student (family member) based on their SWOT profile on a graded scale. Responding to a question (what determines the passing mark?), HHV2 informs, "It is not about passing or failing, the emphasis is on showing consistent improvement on the scale". On each visit, HHV2 assess the daily record book before she conducts a "family meeting" to address successes and challenges in the family. During such meetings, all family members (father, mother, children and relatives) are encouraged to express their opinion freely on any issue. In response to a question, (how was your last visit there?) HHV2 says,

\section{".. I ... pick issues that I identify from the record book and scribble them on pieces of paper, which I will roll-up. Then I call any student to pick a paper and talk about it, while I watch the reactions of the others. This gives me an opportunity to assess their ability of spontaneity and public speaking"- HHV2}

The roles in the family could be shuffled by the 'father', the head of the family in order to give every student the opportunity to play different roles before the expiration of the practice. The head of the family is expected to document and show transparency and be democratic in decision making in order to clear doubts of favouritism or abuse of power. HHV2 explains that the practice is designed "to sustain our long cultural values and belief system, where children are expected to cultivate values from their parents at home, the first informal school for the children". This presupposes that Nigerian undergraduates are expected to retain or improve on what they learn from home in order to sustain their cultural values. Responding to a follow up question (what exactly do you mean by cultural values?), HHV2 responses,

"...the moment we start looking with the 'oyinbo' [foreign] man's lens, we start thinking like him. Our people no longer see anything good around here [Nigeria], they crave for 'anything imported' ... our culture preaches neighbourliness, tolerance, contentment, respect for elders, respect for culture, openness, and agronomics. This is our culture. This is our life"- HHV2

The practice also provides an opportunity for social interaction between the students, while living together and with their lecturers who visits. HHV2 explains that she learns from the students' socio-cultural background, "The students are from different cultural backgrounds and they bring this into their practice. I have learnt many things from them too" Responding to a follow up question (where does the family stay?), HHV2 replies, "The department has an apartment that provides for that purpose".

From the interview with HHV2, the researchers conclude that RHMP imparts an IL component that could be described as an attempt to "sustain the cultural hegemony" (Whitworth 2014) of the Nigeria society. In the Nigerian society, the control and authority is totally surrendered to the head of the family to manage with utmost transparency. The activities in the practice help improve students' skills that can sustain their cultural values. The IL skill that this practice may impact on the students may be that of 'leadership and control' that will be useful as they interact with friends and colleagues during class and other academic activities, as well beneficial in their future workplace. 


\section{Staff Collaboration through Workshops}

In this context, staff collaboration refers to workshop series, where academic members of staff meet to deliberate on how they can assist students in developing entrepreneurial skills, which they could engage in upon graduation from the college. The participant (HCS2) reveals that such skill is needed due to the challenging economic situation in Nigeria, which faces high level of unemployment. Most students are apprehensive about their future upon graduation and this has become a determining factor in enrolling in the department. HCS2 comments, "... we started holding workshop series among ourselves to exchange ideas and prepare ourselves for this new thinking". The collaboration involves sharing of published materials, attending and presenting papers at workshops and also visiting other institutions in Nigeria, where colleagues share solutions to the problem of unemployment. Responding to a probe question (why collaborate to do this?), HCS2 says,

"... During my time, nobody taught me entrepreneurial skill in [...] but today, there's an urgent need for it and that's why we brainstorm and come out with a course like this... We use team-teaching approach because of the various aspects we want the students to know. For example, budgeting, proposal writing, material and equipment sourcing, so many"- HCS2

HCS2 reveals that her colleagues in the department are so committed to the exercise, that "they [we] all agree to shift the preview meeting of the workshops and update on the entrepreneurial course to weekends" Everybody is always punctual and contribute a great deal". To a follow-up question (do you mean the staff benefit more from the workshop series?) HCS2 responses, "It's more about improving the quality of students we turn out and to encourage others to come". The researcher identifies the IL component in this practice as 'information-knowledge sharing' (Kapitzke 2003) as indicated by staff members who share information they have and the experiences they have gathered over the years as individuals and members of various professional groups. Such synergy makes them better informed, and improves learning as well as communication skills such as effective writing, listening, public speaking, group communication, interpersonal, presentation, human relations, and other workplace skills that facilitate routine interactions. Academic staff then impart these IL skills to their students.

\section{Industry Visits}

Industry visits refer to visits to workplaces where students can see the end product of the craft they study in the college such as completed roads, buildings or structures. A participant (HBV1) refers to industry as places where students can see actual examples of designs and construction, on-going or completed. At times formal letters are sent out to estates property managers or colleagues in the industry requesting for a visit. On such occasions, HBV1 says he would educate his students about "why particular designs or shapes are used rather than some other types, which may be as a result of the terrain, the soil formation, utility and government regulations". It is also an opportunity to see trends in the field of architectural design and building, which may not be easily visualized in the classroom.

To a follow-up question (shouldn't photographs or video suffice?), HBV1 says, "the fun and experience of being there is great" and adds that when they return from such visits, the students are expected to write reports and attach photographs, which are kept in the department for future reference by staff and students. From this practice, the researchers conclude that students would gain the IL skill of 'sourcing information from primary sources'. The IL component that is identified, which could nurture this IL skill is 'information sourcing 
and representation' (D'Angelo 2012) because the students have the opportunity of being at the site (industry) where they can see first-hand and gather any information, which may then be represented in their reports or used in other academic activities.

\section{Visiting Localities}

Visiting localities refer to visits to locations, where students could gather information from people who could not codify or write such information. HEL1 explains that there are many languages in Nigeria and very few of them have a written form, which explains why they are only spoken. "Languages can only be codified if they possess autography but will remain in their oral form if they do not possess autography to codify them". He further explains that whoever wishes to know and explore into what information people in a community possess would have to visit the locality. He also explains, "... by the virtue of my area of interest [orature], my main source of information for research and teaching is by visiting the localities where the information is situated".

HEL1 clarifies that secondary information about such communities could be read in books or other media, but the primary sources requires visiting people in their localities. The reliability of such primary sources justify the basis for this practice. Most of the localities have their norms, which visitors are expected to respect when visiting. HEL1 describes how the practice works, "... when we are planning to visit a locality, I liaise with colleagues who are familiar with the community in order to study and master their norms. At times I do visit the place first before taking my students for a visit". The students are tutored on the norms of the locality and shown how to respect them before they proceed on such visits.

Through community visits students are exposed to the IL component of 'information sourcing and representation' (Raju 2013). This practice fosters the drive to identify an information need and consequently locate the appropriate information to satisfy such information need. This component is critical to activities in the undergraduates' academic life. In the course of completing this process (seeking information need and locating information source) under the tutelage of the lecturer (HEL1), the undergraduates are being bequeathed with an IL skill of 'sourcing information from primary sources' (Dorner and Gorman 2011), which is useful in real-life and social contexts like the workplace, where coemployees may need to benefit from the unique experience of seasoned professionals in order to satisfy an information need. This intended IL skill also becomes an asset when the context of information environment has to be studied with care in order to get the best out of it, as HEL1 explains by visiting the location first before the student visits. This precaution is useful when sourcing information from primary sources because people, communities or organisations have their peculiarities, norms and culture regarding information handling.

\section{Networking with Colleagues}

In this context, the participant (HEE2) explains how he contacts his network of friends and contemporaries who are in academic associations, professional bodies, social groups on and outside campus to gather information for academic and other purposes. This practice provides an opportunity for colleagues to learn from one another through formal and informal interactions. HEE2 explains,

"opinions are shared with colleagues who may learn from them, share their experience to shape such opinions or disagree out-rightly on the basis of superior scientific or proven facts" - HEE2. 
HEE2 reveals, "... I do send mails to friends on some issues in order to get more views on the matters and I equally receive similar requests from people asking me one question or the other about a particular issue in my locality or country". This situation reveals that academics network with other people in order to know what goes on in the 'ocean of knowledge'. HEE2 explains what he gains from networking, “... you see, you do not lose anything by networking rather you gain more, at least, by confirming what you have heard or read before. You can really get a novel idea from people and this may mark a turning point" thus underscoring the worth of networking with colleagues."

The IL component that is identified in this practice and transferred to students is 'sourcing for information' (Taylor 2007) while the IL skill that is intended is 'formal and informal retrieval skills' (Lloyd 2010; 2014). The practice involves seeking people 'in the know' (the source) to fulfill an information need. This situation builds the ability to source information, using formal (official requests) and informal approaches (annotating short notes, text messaging (SMS), non-verbal cues, phone calls, or anecdotes). In doing this, lecturers and students are grooming themselves in 'formal and informal retrieval skills', which are used on daily basis in the workplace as tasks may require clarifications, confirmations or request for supporting documents from organisations or colleagues.

\section{Teaching Practice}

The teaching practice is designed as an 'industry practice' and undergraduate students are assigned to primary or secondary schools in the community for a semester while lecturers are assigned to supervise them. This practice exposes the undergraduates to the real world of teaching and prepares the undergraduates to fit into their future workplace. In response to a follow up question (how do you conduct the supervision?), HTE1 explains, "... there is a grading scale, which guides what mark is apportioned to a display of a particular skill during the supervision". In order to be fair to the student on teaching practice, supervisors are expected to submit at least two assessments on each student, while each student has more than one supervisor. Therefore, it is possible for a student to have four or more assessments from which the Coordinating Office will select the best two. In response to a probe question (what is your role in this assessment/supervision?), HTE1 says,

"... my role is to shape the student to become better and that is why the visit cannot be once.... For instance if the marks for appropriate use of instructional materials [IM] is 10 and the student did not use [IM] at all or did not use appropriate ones, my role is to provide a remedial session [post-mortem] to acquaint him or her on the value in using instructional materials."- HTE1.

HTE1 explains that the grading scale is designed to address all aspects of teaching skills expected of a 'good' teacher. Supervisors (including HTE1) goes through teaching practice workshop, where colleagues share experience on how to prepare the undergraduates to be 'best' teachers in the classroom. At such a teaching practice workshop, experienced lecturers share problems related to pedagogy and professional issues as well as experiences and strategies of preparing the undergraduates fit for the teaching workplace. The strategies and skills are mapped onto the grading scale for assessment.

From the interviews with HTE1 and observation during the teaching practice workshop, the researcher identifies the IL component 'professional grooming of novices' (Lloyd 2010), where teacher trainee (undergraduates) are groomed for the workplace. This practice improves the teaching skills of undergraduates and may likely infuse the IL skill of being able to identify the necessary skills that are required in the teaching profession and also sustain the norms in the 'community of practice'. 


\section{Practical Session through Laboratory Activities}

The practice of practical session exposes the learner to laboratory activities that underpin theories of knowledge in science. While theories in the subject of science seem abstract, the participant (HIS1) explains, "it's not easy to define a theory or law without taking the learners through practical demonstrations". Learning is made more effective through seeing, touching, and other sensory organs involved in physical activities (practicals). The practical session brings interactions among the students, lecturer-in-charge of the course, and laboratory technologists. The lecturer coordinates the activities before and during the session to ensure adequate cooperation (team work). HIS1 explains why "some activities are done outside the department because some instrument or specimen may be acquired by the Central Science Purchasing Unit". This shows that lecturers liaise with colleagues outside the department and collaborate with departmental staff to achieve an effective practical session for the students. The learners are expected to learn from the well coordinated activities of the laboratory session and could replicate the practice in both the school or the workplace. The identified IL component in this practice, is 'team work,' (Bruce 2008) while the IL skill that is intended to be bequeathed to the colleagues and students is 'workplace collaboration' (Lloyd 2011; Bruce, Hughes and Somerville 2012).

\section{Micro-teaching}

The practice of micro-teaching involves breaking large classes into smaller (micro) classes of about twenty students or less. The lecturer introduces specific topics to the learners and allows them to share their understanding in the class. After taking the students through the rudiments of a topic, HEA1 indicates,

"I will ask them [students] to do a ten-minute presentation of their understanding of my lecture. This will give me the opportunity to assess their confidence in public speaking, understanding of the subject and how they can explain what they have learnt" - HEA1.

HEA1 further explains that,

"Micro-teaching removes the barriers in a large class and provides the lecturer the opportunity to provide a learner-driven experience".

In micro teaching situations, lecturers are able to analyse and attend to individual feedback from the students thus ensuring that students are taken through a learning experience. In this context, the identified IL component is 'public speaking' (Bruce, Hughes and Somerville 2012) and 'ethical presentation' (Taylor 2007), which the learners could exhibit in the tenminute presentation. Also, the lecturer would have imparted into them the IL skill of 'citation and acknowledgement' because HEA1 says, "I provide citations and references when teaching" and he expects them to also provide "citations and acknowledgement of whoever helped you [them] in getting information".

Over time, IL skills that are highlighted above are shared and may be passed onto colleagues and students who co-participate in such activities. While some skills may evolve in the 'doas-I-do' routines, some may be cultivated through interactions between people, artefacts, texts and bodily experiences that enable persons to develop both subjective and intersubjective positions. Table 1 summarizes the eight (8) practices that academics are involved by virtue of their roles in a college in Nigeria, and alongside each practices, are listed the identified IL component and IL skills that evolve and transferred to the undergraduates. 
Jinadu, I., \& Kiran, $K$.

Table 1: Academic Practices and the Resultant Information Literacy Component and Skills

\begin{tabular}{l||l||l}
\hline \hline Practices & Identified IL components & IL skills intended \\
\hline $\begin{array}{l}\text { Residential home management } \\
\text { practices (RHMP) }\end{array}$ & Cultural hegemony & Leadership and control \\
\hline $\begin{array}{l}\text { Staff collaboration through } \\
\text { workshops }\end{array}$ & $\begin{array}{l}\text { Information-Knowledge } \\
\text { sharing }\end{array}$ & Communication skills \\
\hline Industry visits & $\begin{array}{l}\text { Information sourcing and } \\
\text { representation }\end{array}$ & $\begin{array}{l}\text { Sourcing information from } \\
\text { primary sources }\end{array}$ \\
\hline Visiting localities & $\begin{array}{l}\text { Information sourcing and } \\
\text { representation }\end{array}$ & $\begin{array}{l}\text { Sourcing information from } \\
\text { primary sources }\end{array}$ \\
\hline Networking with colleagues & Sourcing for information & $\begin{array}{l}\text { Formal and informal retrieval } \\
\text { skills }\end{array}$ \\
\hline Teaching practice & $\begin{array}{l}\text { Professionals grooming } \\
\text { the novice }\end{array}$ & $\begin{array}{l}\text { Sustaining the norms in the } \\
\text { community of practice }\end{array}$ \\
\hline Practical session in laboratories & Team work & \begin{tabular}{l} 
Workplace collaboration \\
\hline Micro-teaching
\end{tabular} \\
\hline \hline
\end{tabular}

\section{DISCUSSION}

The work roles and practices of teachers or academics are profiled in a number of studies in literature and there is concensus that each practice triggers IL skills on a continuum from the abilities to identify information need and justify the choice of what information best solves a problem. What constitutes a problem therefore is relative, subjective and contextual. Through the descriptions of responses from the nine academic participants in a Nigerian college this study identifies two main categories of practices; academic-related and social / professional related.

The first relates to academic practices encompass through the practice of staff collaboration through seminars and workshops, industry visits, staff and student networking, practical sessions in laboratories and group interaction in micro teaching. The majority of the practices indicated in Table 1 are academic related, which transfers IL skills in the form of being able to seek information from sources, retrieve from both formal and informal sources, collaborate in teams, communicate and share knowledge, write and present findings, and ethically cite all sources used. Lloyd (2010) explains that the execution of tasks in the workplace is interactional, inter-subjective, and co-participatory. The practice of 'staff collaboration' and 'networking with colleagues' is described by the academic participants, as the sharing of experiences and resources and results in 'knowledge sharing' of how to source for both formal and informal information. Through engagements in workshops and other academic forums, the academics share knowledge, prepare themselves and imbued the experiences to tasks set for their undergraduates. Sharing and networking nurtures communication skills as well as formal and informal retrieval skills. D'Angelo (2012) argues that effective communication and organisation skills are transferable skills and affirms that "writing and communication of information are components of IL" (p. 639). This finding infers that staff collaboration and networking would cultivate and sustain all communication skills and result in the transference of IL. Also, the micro teaching practices, nurtures 'public speaking and ethical presentation' which are affirmed by IL standards. Whichever way the information is used, either in speaking or writing, students are made aware to use sources ethically through adequate citation, referencing and acknowledgements. This perspective underpinned the call by 
scholars for the integration of IL across curricula in order to extend the skills of information sourcing and avoid plagiarism.

The second category of skills refer to social and professional related practices. Through the unique practice of residential home role play, 'cultural hegemony', a component of IL is observed from practices to groom a responsible citizenship. The IL skills acquired in this practice would be relevant to the students' social interaction in their future workplace and uniquely found in this Nigerian context. The family role play nurtures the ability to adjust to democratic processes, contribute to citizenship and governance, which are contextspecific ways of thinking and making decisions both as a leader and a follower. The students learn how to assume good leadership practices and how to control and use various media to bring information within their sphere of influence and balance the demands of the modern workplace and their own cultural norms and practices. The professional related practices are enacted through the teaching practice programmes imparting undergraduates to the accepted norms of good teaching practitioners in Nigerian schools.

\section{CONCLUSION}

The workplace provides the opportunity for employees, in this case the academics, to initiate and engage in practices that enable them prepare undergraduates with information literacy skills. When tasks are carried out at any of the stages in the workplace, there are some embodiments of skills in the practices, captured as 'IL skill intended'. Over time, such skills that are shared are passed onto colleagues and students who coparticipate in activities that are presently restricted to the classrooms. While some skills may evolve in the 'do-as-I-do' routines, some may be cultivated through the connections that exist between people, artefacts, texts and bodily experiences that enable persons to develop both subjective and inter-subjective positions. As people in-the-know, academics share knowledge and experiences with colleagues in the community of practice in order to further prepare their undergraduates for acceptable performance both in college and their future workplace. IL skills would evolve in the interactions as these become routine practices thus opening up a new landscape of information practices through which IL may evolve in the classroom and beyond. The individualistic approach that underlies classroom activities may not be enough to adequately prepare the undergraduates with the skills necessary to participate actively in the workplace. This study has opened up the need for future tracer studies that could investigate how other factors hinder or facilitate the performance of graduates (employees) in the workplace.

\section{ACKNOWLEDGMENT}

This work was funded by University of Malaya, Grant FL003-2012.

\section{REFERENCES}

Bitso, C. and Fourie, I. 2012. An investigation of information-seeking behaviour of geography teachers for an information service intervention: the case of Lesotho. Information Research, Vol. 17, no. 4, Paper 549. Available at: http://www.informationr.net/ir/17-4/paper549.html\#.VHv-GvmsUzM. 
Boon, S., Johnston, B. and Webber, S. 2007. A phenomenographic study of English faculty's conceptions of information literacy. Journal of Documentation, Vol. 63, no. 2: 204228.

Bruce, C. 1997. The seven faces of information literacy. Adelaide: Auslib Press.

Bruce, C. 2008. Informed learning. Chicago, III.: Association of College and Research Libraries.

Bruce, C., Hughes, H. and Somerville, M. M. 2012. Supporting informed learners in the twenty-first century. Library Trends, Vol. 60, no. 3: 522-545.

Cheuk, B. 1998. An experienced-based information literacy model in the workplace: Case studies from Singapore. In Information literacy: The professional issue. Proceedings of the $3^{\text {rd }}$ Australian National Information Literacy Conference, Canberra (pp. 74-82). Adelaide, SA: University of South Australia Library.

Cox, A. M. 2012a. Information in social practice: A practice approach to understanding information activities in personal photography. Journal of Information Science, Vol. 39, no. 1: 61-72

Cox, A. M. 2012b. An exploration of the practice approach and its place in information science. Journal of Information Science, Vol. 38, no. 2: 176-188.

Crawford, J. 2013. Information literacy and lifelong learning: Policy issues, the workplace, health and public libraries. Oxford: Chandos Publishing.

D’Angelo, B. 2012. Student learning and workplace: A case study. Library Trends, Vol. 60, no. 3: 637-650.

Dorner, D.G. and Gorman, G.E. 2011. Contextual factors affecting learning in Laos and the implications for information literacy education. Information Research, Vol. 15, no.1: paper 479. Available at http://InformationR.net/ir/16-2/paper479.html.

Jinadu, I. and Kiran, K. 2014. Information literacy at the workplace: A suggested model for a developing country. Libri, Vol. 64, no. 1: 61-74.

Kapitzke, C. 2003. Information literacy: A review and post-structural critique. Australian Journal of Language and Literacy, Vol. 26, no. 1: 53-66.

Kirk, J. 2004. Tumble dryers and jugger-naughts: Information use processes in organisations. In Lifelong learning: Whose responsibility and what is your contribution? Proceedings of the 3rd International lifelong learning conference, Yeppoon, Queensland, Australia (pp.192-197). Rockhampton: Central Queensland University Press.

Koster, B., Brekelmans, M., Korthagen, F., and Wubbels, T. 2005. Quality requirements for teacher educators. Teaching and Teacher Education, Vol. 21, no. 2: 157-176.

Lloyd, A. 2007. Recasting information literacy as sociocultural practice: Implications for library and information science researchers. Information Research, Vol. 12, no. 4: 114.

Lloyd, A. 2010. Information literacy landscapes: Information literacy in education, workplace and everyday contexts. London: Chandos Publishing.

Lloyd, A. 2011. Trapped between a rock and a hard place: What counts as information literacy in the workplace and how is it conceptualised? Library Trends, Vol. 60, no. 1: 277-296.

Lloyd, A. 2014. Following the red thread of information in information literacy research: Recovering local knowledge through interview to the double (ITTD). Library \& Information Science Research, Vol. 36, no. 2: 99-105.

Merriam, S. B. 2001. Qualitative research and case study applications in Education. San Francisco: Jossey-Bass.

Moring, A. and Lloyd, A. 2013. Analytical implications of using practice theory in workplace information literacy research. Information Research, Vol. 18, no. 3: 1-9. Available at: http://www.informationr.net/ir/18-3/colis/paperC35.html\#.VsREgXJ97IU. 
Neuman, W. L. 2011. Social research methods: Qualitative and quantitative approaches $\left(7^{\text {th }}\right.$ ed.). New York: Pearson.

Rader, H. 2002. Information literacy 1973-2002: A selected literature review. Library Trends, Vol. 51, no. 2: 242-261.

Raju, J. 2013. Viewing higher education information literacy through the African context lens. African Journal of Library, Archival and Information Science, Vol. 23, no. 2: 105111.

Reckwitz, A. 2002. Toward a theory of social practice. A development in culturalist theorizing. European Journal of Social Theory, Vol. 5, no. 2: 243-63.

Ross, M, Perkins, H., \& Bodey, K. 2013. Information literacy self-efficacy: The effect of juggling work and study. Library \& Information Science Research, Vol. 35, no. 4: 279287.

Salau, G. 2012a, June 6. Nigeria lags behind its peers. The Guardian, p.16. Available at: www.ngrguardiannews.com.

Salau, G. 2012b, September 30. With careful planning, we will transform Nigeria. The Sunday Guardian, p. 28. Available at: www.ngrguardiannews.com.

Smith, K. 2005. Teacher educators' expertise: What do novice teachers and teacher educators say? Teaching and Teacher Education, Vol. 21: 177-192.

Taylor, T. 2007. 100\% Information literacy success. New York: Thomson Delmar Learning.

Veinot, T. 2007. The eyes of the power company: Workplace information literacy practices of a vault inspector. Library Quarterly, Vol. 77, no. 2: 157-179.

Virkus, S. 2003. Information Literacy in Europe: a literature review. Information Research, Vol. 8, no. 4, Paper no 159. Available at: http://informationr.net/ir/84/paper159.html.

Virkus, S. 2011. Information literacy as an important competency for the $21^{\text {st }}$ century: Conceptual approaches. Journal of the Bangladesh Association of Young Researchers, Vol. 1, no. 2: 15-29.

Wang, L., Bruce, C. S. and Hughes, H. E. 2011. Sociocultural Theories and their application in information literacy research and education. Australian Academic and Research Libraries, Vol. 42, no. 4: 296-308.

Wenger, E. 1998. Communities of practice: Learning, meaning and identity. Cambridge: Cambridge University Press.

Whitworth, A. 2014. Radical information literacy: Reclaiming the political heart of the information literacy movement. London: Chandos Publishing.

Yin, R.K. 2011. Qualitative research from start to finish. New York: The Guildford Press.

Zurkowski, P. 1974. The Information service environment: Relationships and priorities. Washington, DC: National Commission on Libraries and Information Science. Available at: http://files.eric.ed.gov/fulltext/ED100391.pdf. 